\title{
ACID-BASE ASPECTS OF SHELL GIAND FUNCTION IN THE DOMESTIC FOWL
}

\author{
K. SIMKISS and H. Alison DUCKER \\ Deparment of Zoology and Comparative Physiology, \\ Quen Mary College, London E 1 (creat Britain) \\ Dopartment of Physiology and Biochemistry, \\ The University, Reading, Berkshire (Great-Britain)
}

\section{IN'IRODUCTION}

The importance of acid-base balance in problems of calcification has been emphasized in a number of different ways in recent studies (MongIN, I968; Simkiss, I968 $a, b$.). Much of the impetus to stuch work came from the elegant results obtained by MoNGIN and IAACASSAGNE ( $\mathrm{Ig}^{64}$ ) in their work on the variations of blood $\mathrm{pH}, \mathrm{pCO}_{2}$ and bicarbonate during the laying cycle of the fowl. 'This work was followed by a demonstration of renal responses in that the $\mathrm{pH}$ (ANDERSON, I967) and electrolyte composition (MONGIN and LACASSAGNE, 1967 ; 'TAYLOR and KIRKI,IY, I967) of the urine changed during laying days. There is also a pulmonary compensation (MoNGIN and LACASSAGNE, 1965) which indicates that the acidosis observed during shell formation leads to a number of compensatory adjustments in the bird.

In recent years we have made a number of observations on some of these processes. The results are put together in this paper in the hope that they will indicate the direction of our work and the way it appears to confirm or contradict the results of other workers. It should be emphasized, however, that a number of our observations are preliminary and are based npon small numbers of experiments. To that extent this paper represents little more than a review and progress report of work from our laboratory.

\section{MATERIALS AND METHODS}

Most of the work described in this paper has been performed upon two strains of domestic fowl, namely Thornbers 404 's and Arbor Acres. Two colostomized cocks have also been used one of which was a Thornber 404 (cock I) while the other was a Southdown broiler (cock 2).

The intracellular $\mathrm{pH}$ of the shell gland of laying birds was measured by the method of WADDELL and ButLer (I959). This method depends upon the distribution of the drug $5-5$ dimethyl 2-4 oxazolidene dione (DMO) between the intracellular and extracellular water. The size of these fluid compartments was assessed by using three different methods utilizing endogenous chloride 
or exogenous thiocyanate or inulin. The details of these methods are given elsewhere (Simkiss, 1969). The intracellular pH of the shell gland was calculated from the equation

where

$$
\mathrm{pH} i=\mathrm{pK}^{1}+\log \left\{\left[\frac{\mathrm{C}_{t}}{\mathrm{C}_{e}}\left(\mathbf{I}+\frac{\mathrm{V}_{e}}{\mathrm{~V} i}\right)-\frac{\mathrm{V}_{e}}{\mathrm{~V} i}\right] \times\left[\mathrm{Io}^{\left(\mathrm{pH}_{e}-\mathrm{pK}^{1}\right)}+\mathbf{I}\right]-\mathbf{I}\right\}
$$

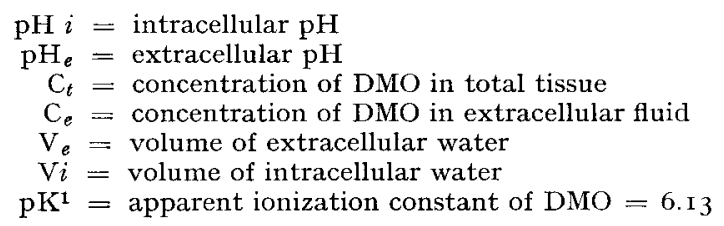

The $\mathrm{pH}$ of the blood was measured with a Radiometer microelectrode system and the $\mathrm{PCO}_{2}$ was determined with the Astrup microtonometer and the extrapolation method of SIGGARD Andersen (1965). Samples of fluid obtained from the shell gland during calcification were collected into capillary tubes and analysed similarly.

Volatile carbonates in the urine and faeces were determined by CoNway's (I962) microdiffusion methods and will be referred to as "bicarbonate", although small amounts may exist in other forms. Ammonia was estimated after steam distillation into boric acid solutions followed by titration with hydrochloric acid. Calcium was determined with a HILGER and WATTS atomic absorption spectrophotometer.

\section{RESULTS}

The changes in the intracellular $\mathrm{pH}$ of the shell gland are shown in figure $\mathrm{I}$ as the differences between extracellular and intracellular $\mathrm{pH}$ during the process of shell formation. The same results are shown in figure 2 plotted against the time of day.

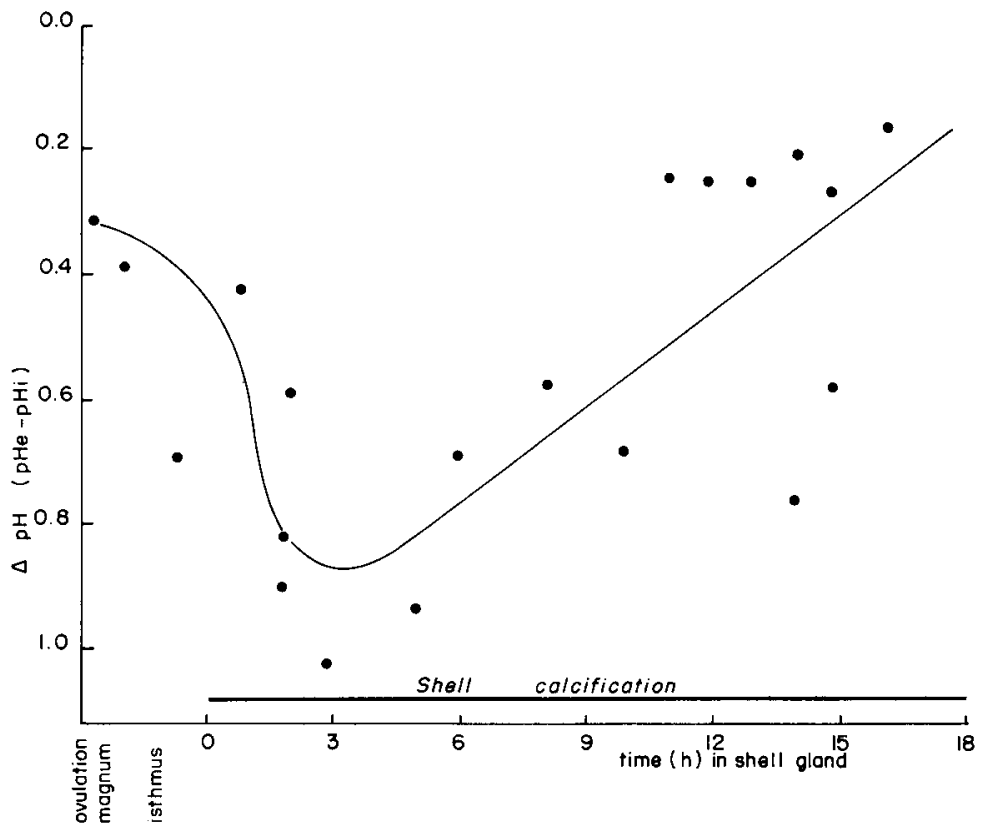

Fig. 1. - Changes in intracellular $p H$ of the shell gland during eggshell calcification

The results are plotted as the difference in $\mathrm{pH}$ between the plasma and the cells (pHe-pHi) and include values for the $\mathrm{pH}$ of the shell gland at the time when the egg is being ovulated and while it is in the magnum and isthmus. 
Changes in the $\mathrm{pH}$, ammonia and bicarbonate content of the urine of a colostomized laying hen and a male bird (cock $\mathbf{I})$ are shown in fig. 3 in relation to time of day and laying cycle.

Analyses of the fæces of colostomized birds are shown in table $I$.

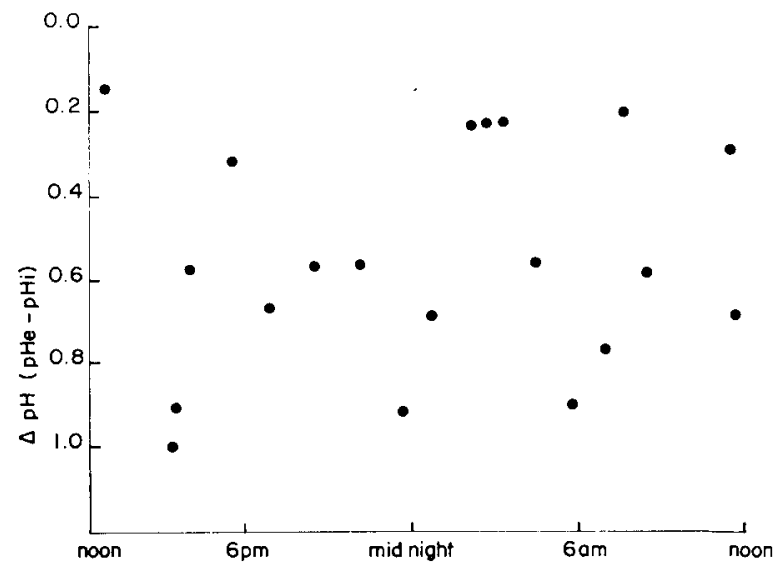

FIG. 2. - Values for the intracellular $p H$ of the shell gland as in fig. 1 but plotted against time of day instead of stage of shell formation

\section{DISCUSSION}

There is probably sufficient mineral in the diet of most laying fowl to supply directly the calcium carbonate required for the eggshell. If the food was used in this way there would be no obvious reason why the calcium or acid-base metabolism of the bird should be disturbed during shell formation. Since it is well documented, however, that both these aspects of avian physiology are disturbed during reproduction it is worth considering the fate of these dietary minerals in the laying bird. Unfortunately, there is remarkably little information upon this subject although the analyses of TYLER (I946) clearly demonstrated that two phenomena occur. First the calcium carbonate in the diet is destroyed when the food enters the stomach and gizzard and comes into contact with the gastric fluids. Thus the secretion of hydro-

TABLE I

Composition of the faeces (per $\mathrm{g}$ dry matter) of a colostomized cock and laying hen fed on the same diet

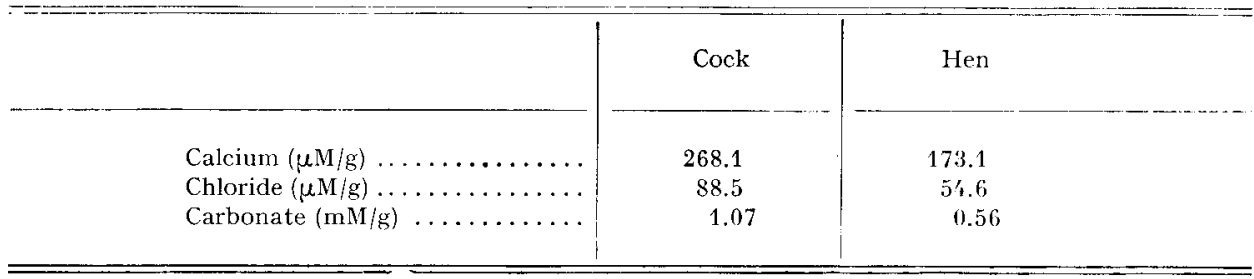


chloric acid destroys the dietary calcium carbonate, but its secretion is accompanied by the release of an equivalent amount of bicarbonate ions into the blood stream. As the food then passes along the alimentary canal a second process occurs, namely a resorption of intestinal chloride in exchange for plasma bicarbonate. This leads to a reprecipitation of calcium carbonate which therefore reappears in the distal parts of the alimentary canal. TYLER found, however, that there was less carbonate in the faces of laying as opposed to non-laying birds. Our own sparse evidence tends to confirm this hypothesis since there is more calcium and carbonate in the freces of a cock than in those of a laying hen (table I). It should be emphasized, however, that these analyses are based upon percentage composition and not upon a complete analysis of daily intake and retention of carbonate.
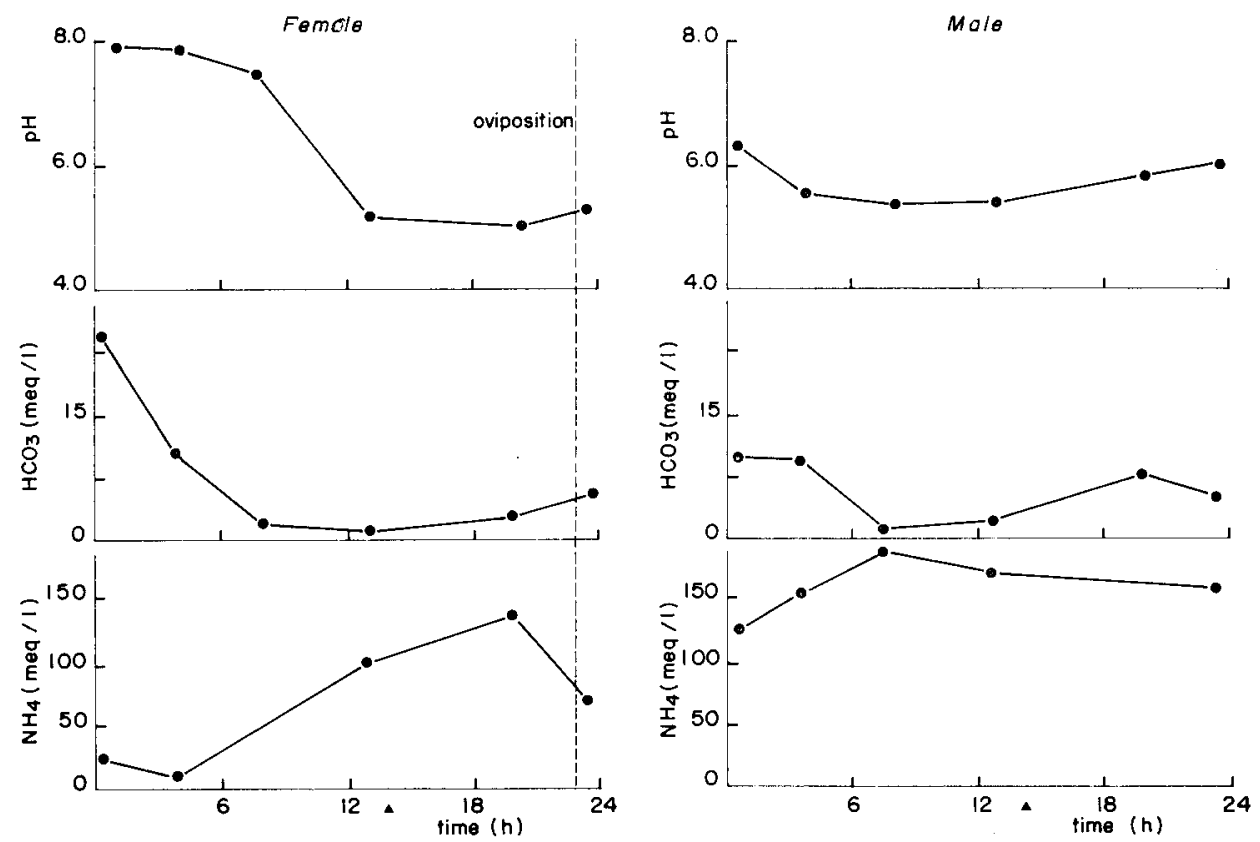

IIG. 3. - The pH, bicarbonate and ammonia content of the urine of a colostomized laying hen and a colostomized male bird (cock $\mathrm{I}$ ) both fed on the same diet

Oviposition is shown by a broken vertical line and mid-night is indicated by the triangle

There is, however, confirmatory evidence for this hypothesis for it was first noticed by Common (I94I) and later by Mongin and LACASSAGNE (I964) that there was a higher concentration of bicarbonate in the plasma of a laying hen than in a cock. Our own analyses of urine from colostomized birds indicate that the same sex difference occurs here. Thus, between periods of shell calcification the urine of laying birds reaches a $\mathrm{pH}$ of as much as 7.5 to 8.0 when birds are fed on a normal commercial laying ration. A colostomized cock, kept on the same diet for most of its life will produce a urine with a $\mathrm{pH}$ of about 6.0 to 6.5 . Bicarbonate and ammonia concentrations are as might be expected for these different $\mathrm{pH}$ values (fig. 3 ). Thus, again there is a sex difference between the birds with the hen being in a state of alkalosis relative to the cock. When the female bird forms an eggshell there is a fall in the 
$\mathrm{pH}$ and bicarbonate concentration of the urine but whereas ANDERSON (I967) interprets this as a renal response to an acidosis induced by shell formation, it could be pointed out that the urine is, in fact, only approaching in composition that of a nonlaying hen or cock. These results are interpreted by us as indicating that in the laying bird there is some process tending to retain bicarbonate and put the female bird into a state of alkalosis prior to the acidosis imposed by shell formation. (SIMKISs, I970).

The fate of this bicarbonate during shell formation is a matter of some conjecture. According to the theory of Gurowska and MiTchell (1945) two bicarbonate ions condense to form carbonic acid and a carbonate ion. An alternative theory suggests that the carbonate of the shell is derived from carbon dioxide (SImkIss, I96I ; Diamaxstein, I966; HoDGEs and Lörcher, I967). The problem is complicated because the carbon dioxide-bicarbonate system performs two separate functions during shell formation. First it provides the necessary molecules from which the carbonate ion is derived and second it is involved in buffering the protons which are released during the calcification process. It is the disentangling of this dual role which has given rise to so much confusion in these studies and which led us to attempt to approach the problem in a slightly different way.

It is apparent from our estimates of intracellular $\mathrm{pH}$ in the shell gland that there is a rapid fall at the start of calcification followed by a slow rise back to resting values. It was shown by Mongin and LACASSAGNe (1964) that there was a fall in blood $\mathrm{pH}$ during shell formation and to eliminate this effect our results are plotted as the change in the difference in $\mathrm{pH}$ between intracellular and extracellular $\mathrm{pH}$ (fig. I). There is already some evidence that the oviduct is capable of modifying its $\mathrm{pH}$ to a limited extent (OGASAwara, VaN KREY and LORENZ, I964) and does in fact have a circadian rhythm of such activity (Winget, MEPHAM and AVERKIN, I965). This is, however, a rather different phenomenon from that reported here since plotting our data against time of day reveals no such rhythm (fig. 2). It should be emphasized that the change in intracellular $\mathrm{pH}$ is however an average value for all the cells in the shell gland and not just those involved in shell formation. The figures have, therefore, no absolute value and merely indicate the changes which are occurring.

Changes in intracellular $\mathrm{pH}$ due to active secretion are most easily envisaged as being due to a splitting of water into protons and hydroxyl ions. The process is similar to that occurring in the gastric mucosa except that instead of secreting protons and retaining hydroxyl ions the shell gland secretes hydroxyl ions and retains the protons causing a fall in intracellular $\mathrm{pH}$. The splitting of water probably actually occurs by the removal of an electron from a hydrogen atom and its transfer through the cytochrome system to react with water and oxygen and form hydroxyl ions (ROBERTSON, I968). It is interesting to note here the importance of the mitochondria in the transfer of this electron especially in view of the importance attached to this organelle in the transfer of calcium within the shell gland (HoHMAN and ScHraER, I966).

The proton released during this process passes out of the shell gland into the blood where it is buffered by the protein and bicarbonate systems and induces the state of acidosis first described by Mongin and Lacassagne (I964). The hydroxyl ion passes into the lumen of the shell gland and is involved in the formation of the carbonate ion. 
Our values for the $\mathrm{pH}$ of the fluid in the shell gland vary with their method of collection. If the fluid is expressed from the conscious bird it has a $\mathrm{pH}$ of about 7.6 to 7.8 and a $\mathrm{pCO}_{2}$ of about 60 to $80 \mathrm{~mm} \mathrm{Hg}$ which is similar to the values obtained by EL, JACK and LAKE (I967). If, however, the birds are first killed and bled before the removal of the shell gland we obtain fluid with a $\mathrm{pH}$ of about 7.I to 7.2 and a $\mathrm{pCO}_{2}$ of up to $200 \mathrm{~mm} \mathrm{Hg}$. Fluid obtained by either of the two methods gives about the same $\mathrm{pH}$ if it is equilibrated at a constant carbon dioxide tension. This suggests that the difference is due to a very rapid rise in $\mathrm{pCO}_{2}$ in the shell gland after killing the bird. Furthermore, the fact that the $\mathrm{pCO}_{2}$ is normally above that of the other body fluids indicates that it must normally be maintained by some physiological process and this process is presumably uncoupled rapidly after death.

It must be stressed that these are preliminary results and the following is, therefore, a very tentative explanation. It implies that the fall in intracellular $\mathrm{pH}$ leads to a reaction between protons and bicarbonate ions either within the blood or within the oviduct cells. The concentration of bicarbonate found within, for example, muscle cells and the intracellular $\mathrm{pH}$ determined could lead to $\mathrm{pCO}_{2}$ values of the magnitude reported. The carbon dioxide thus generated could pass into the lumen of the shell

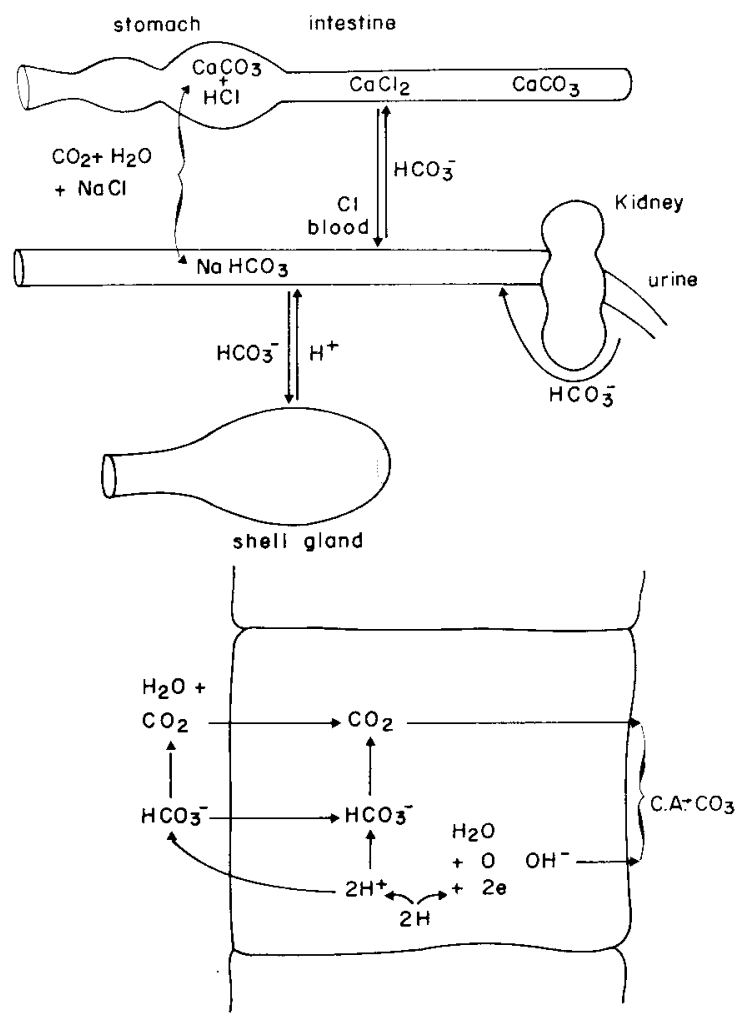

FIG. 4. - A scheme showing the interrelationships of bicarbonate with sone of the organs influenced during eggshell formation

At the bottom is a scheme indicating how a cell of the shell gland could modify the blood (on the left) and eventually produce carbonate ions in the lumen of the oviduct (on the right). C. A. = carbonic anhydrase. 
gland where an equivalent amount of hydroxyl ions would lead to the formation of shell carbonate.

A summary of these concepts of shell formation is given in fig. 4 .

\author{
SUMMARY
}

It is well known that shell formation induces a metabolic acidosis in the laying hen which leads to respiratory and renal compensations. Thus, it is confirmed that there is a fall in urine $\mathrm{pH}$ from values of about 8.0 to below 6.0 during shell calcification. In the cock, however, the urine is normally about pH 6. It appears, therefore, that the laying hen is in a state of induced alkalosis prior to the aciclosis of eggshell formation. This may be due to differences in the functioning of the alimentary canal or the kidney. Superimposed upon these aclaptations is the activity of the oviduct.

The intracellular $\mathrm{pH}$ of the shell gland of the domestic fowl has been measured at various stages of eggshell formation. There is a rapid fall in the $\mathrm{pH}$ of these cells at the start of shell calcification followed by a progressive rise back to resting values (about $\mathrm{pH} 7.0$ ). It is suggested that these changes occur due to the separation of hydroxyl ions and protons. 'The hydroxyl ions pass into the lumen of the shell gland and form carbonate ions by reacting with carbon dioxide in the presence of the enzyme carbonic anhydrase. The protons, which cause the fall in intracellular pH, pass into the blood causing the acidosis which occurs during shell formation.

There are, therefore, two parts to these acid-base aspects of shell formation. The first consists of a buffering of protons by blood proteins and bicarbonate ions and is related to the excretion of protons by the shell gland. The second consists of a movement of carbon dioxide or its hydration products from the blood into the lumen of the oviduct where they react with the hydroxyl ions.

\title{
RÉSUMÉ
}

\section{ÍQUIIIBRE ACIDO-BASIQUE DE L'UTÉRUS CHEZ LA POUI, PONDEUSE}

Il est bien connu que la formation de la coquille produit chez la poule pondeuse une acidose métabolique cntraînant une compensation respiratoire et rénale. Ainsi il est confirmé que le pH de I'urine diminue de 8,0 jusqu'en dessous de 6,o pendant la calcification de la coquille. Chez le Coq, cependant, l'urine est généralement de $\mathrm{pH}$ 6. Il apparaît donc que la poule est en état d'alcalose provoquée avant que ne se déclenche l'acidose liée à la formation de la coquille. Ceci peut être dû à des clifférences de fonctionnement du canal alimentaire ou du rein, l'activité de l'oviducte venant se superposer à ces adaptations.

Le pH intracellulaire de l'utérus de la poule domestique a été mesuré à différents stades de la formation de la coquille. Il se produit un abaissement rapide du pH de ces cellules au début de la calcification de la coquille, suivi d'un retour progressif aux valeurs de repos (pH 7 environ). Nous suggérons que ces changements soient causés par la séparation des ions hydroxyles et des protons. Les ions hydroxyles passent dans la lumière de l'utérus et forment des ions carbonates par réaction avec l'acide carbonique en présence d'un enzyme, l'anhydrase carbonique. Les protons, qui entraînent l'abaissement du pH intracellulaire, passent dans le sang et provoquent l'acidose observée pendant la formation de la coquille.

Nous pouvons par conséquent distinguer deux aspects dans l'équilibre acido-basique de la formation de la coquille. Le premier consiste en un tamponnement des protons par les protéines et les ions bicarbonates du sang et est lié à l'excrétion de protons par l'utérus. Le second consiste en un mouvement de gaz carbonique ou de ses produits d'hydratation depuis le sang jusque dans la lumière de l'oviducte, où ils réagissent avec les ions hydroxyles. 


\section{REFERENCES}

Anderson R. S., 1967. Acid-base changes in the excreta of the laying hen. Vet. Rec., 80, 3I4-5.

Common R. H., I94I. Observations on the mineral metabolism of pullets. V. Acid-base equilibrium and reproductive activity. J. agric. Sci, 31, 28I-94.

Conway E. J., I962. Microdiffusion analysis and volumetric error. 5 th ed. Crosby Lockwood. London.

Diamantstern T., Ig66. Über die lokale Rolle der Carboanhydratase im Hinblick auf die Eischalenkverkalkung. Arch. Geflugelk, 30, 309-20.

EL JACK M. H., LAKE P. E., 1967. The content of the principal inorganic ions and carbon dioxide in uterine fluids of the domestic hen. J. Reprod. Fert., 13, 127-32.

Gutowska M. S., Mirchell $\quad$ C. A., I945. Carbonic anhydrase in the calcification of the eggshell. Poultry Sci., 24, I59-67.

Hodges R. D., Lörcher K., r967. Possible sources of the carbonate fraction of eggshell calcium carbonate. Nature, London, 216, 609-ro.

Hohman H., Schraer W., I966. The intracellular distribution of calcium in the mucosa of the avian shell gland, J. Cell. Biol., 30, 317-3I.

Mongin P., r968. Role of acid-base balance in the physiology of eggshell formation. World Poultry Sci. J., 24, $200-230$.

Mongin P., Lacassagne L., I964. Physiologie de la formation de la coquille de l'œuf et équilibre acidobasique. C. R. Acad. Sci., 258, 3093-4.

Mongin P., Lacassagne I., I965. Physiologie de la formation de la coquille de l'œuf et ventilation pulmonaire. C. R. Acad. Sci., 261, 4228-30.

Mongin P., Lacassagne L., I967. Excrétion urinaire chez la poule au moment de la ponte de son premier œuf. C. R. Acad. Sci., 264, 2479-80.

Ogasawara F. X., Van Krey H. P., Lorksz F. W., I964. Hydrogen ion concentration of the oviduct of the laying domestic fowl. Poultry Sci., 43, 3-6.

Robertson R-N., I968. Protons, electrons, phosphorylation and active transport. Cambridge University Press.

SiggaARd-Andersen $\quad$ O., I965. The acid-base status of the blood. 3 rd ed. I34 pp. Munksgaard. Copenhagen.

Simkiss K., I96I. Calcium metabolism during avian reproduction. Biol. Rev., 36, 32 I-67.

Siмкiss K., I968a. Mineral deposits and Acid-base regulation. Third conference on the biology of hard tissues. New York Acad. Sci. (in preparation).

Simkiss K., I968b. The structure and formation of the shell and shell membranes. In CARTER T. C. Egg quality. A study of the hen's egg. (BEMB symposium no 4 ), 3-25, OLrver and Boyd, Edinburgh.

Simkiss K., I969. Intracellular $\mathrm{pH}$ during calcification. A study of the avian shell gland. Biochem.J. 111, $647-652$.

Simkiss K., I970. Asex difference in the a cid base balance of adult and immature birds. Comp. Biochem. Physiol. (in press).

TAYloR T. G., KiRkLey J., I967. The absorption and excretion of minerals by laying hens in relation to eggshell formation. Brit. Poultry Sci., 8, 289-95.

TYLER C., I946. Studies in the absorption and excretion of certain minerals by poultry. II. J. agric. Sci., Camb., 36, 275-82.

Waddell W. J., Butler T. C., r959. Calculation of intracellular pH from the distribution of 5-5 dimethyl 2,4, oxazolidinedione (DMO). Application to skeletal muscle of the dog. J. Clin. Invest., 38, $720-9$.

Winget C. M., Mepham C. A., Averkin E. G., i965. Variations in intra-uterine pH within a circa* dian rhythm (Gallus domesticus). Amer. J. Physiol., 208, I031-5. 